\title{
Different Criteria for Feed Formulation Based on Digestible Amino Acids for Broilers
}

Quthor(s)
Araújo $\mathrm{LF}^{1 *}$
Junqueira $\mathrm{OM}^{2}$
Araújo CSS²
Laurentiz $\mathrm{AC}^{3}$
Assuena V²
Gomes GA
1 Animal Science Department, University of
São Paulo (USP), Pirassununga.
2 Animal Science Department, FCAV, São
Paulo State University, Jaboticabal.
3 Animal Science School, São Paulo State
University (UNESP), Dracena.

Mail Address

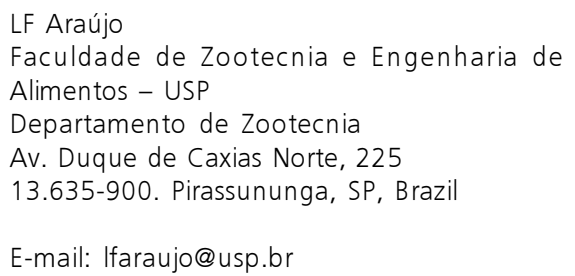

\section{Keywords}

Broilers, carcass yield, digestible amino acids, performance.

\section{ABSTRACT}

An experiment was carried out to evaluate different criteria in feed formulation based on digestible amino acids for broilers during the grower phase. Diets were formulated according to the recommendations for digestible methionine, methionine + cysteine, lysine, and threonine. A total number of six hundred Cobb 500 male day-old chicks were distributed in a completely randomized experimental design, with three formulation criteria supplying the recommendations established by Baker \& Chung (1992), Degussa (1997), and Rostagno et al. (2000), with 4 replicates of 50 birds each. No significant differences were observed for weight gain and feed intake. However, feed conversion ratio improved when birds were fed the diets containing the profiles recommended by Baker \& Chung (1992) and Degussa (1997). No difference was observed in terms of leg, wings, back, and head yields. Broilers fed with the profile of Baker \& Chung (1992) presented worst breast yield, whereas those fed the Degussa (1997) standard had better carcass yield.

\section{INTRODUCTION}

An important function of animal production is to provide high-quality protein for human consumption. In order to fulfill this role, animals themselves require high-quality protein in correct proportions in their diets. There are many ways to assess the quality of proteins, but nevertheless they are all related to amino acid supply, which thus becomes a key feature in animal nutrition. For many years, poultry feed formulation was based on the concept of crude protein, which often resulted in higher amino acid levels than those required by the birds. Birds are not able to properly utilize this excess of amino acids, which is reduced to nitrogen and excreted as uric acid. Excessive protein levels in the feed do not only mean high formulation costs, but can also affect poultry performance. When synthetic amino acids became commercially available, nutritionists started to formulate lower cost feeds, with a proper level of amino acids, but still used high protein levels. Birds do not require high crude protein in the feed, but merely an amount that ensures sufficient nitrogen reserve for the synthesis of non-essential amino acids. As the number of economically available synthetic amino acids increase, the crude protein level will be increasingly reduced. According to Pack (1995), amino acid requirements must indubitably be expressed on digestible base, instead of total base.

It is known that many factors influence broilers amino acid requirements. However, it is virtually impossible to carry out all the possible combinations in dose-response experiments, and to individually observe the response to essential amino acids. Fernandez et al. (1994) showed that these problems can be solved with diets formulated on 


\section{Araújo LF, Junqueira OM, Araújo CSS, Laurentiz AC, Assuena V, Gomes GA}

the concept of ideal protein. The biggest advantage of using the ideal protein profile is that it can easily be adapted to different circumstances, as the ideal ratios remain relatively stable, regardless the changes of the nutritional plan of amino acids.

The interactions among dietary amino acids must be considered. There will be a response to lysine only if methionine is adequately supplied, showing the importance of providing a well-balanced amino acid profile. Kidd et al. (1997) reported an interaction between lysine and threonine on weight gain and lean tissue yield of broilers slaughtered at 54 days of age, where high dietary lysine concentrations, without considering threonine levels, limited performance.

When maintenance requirements are considered, the levels of sulfur amino acids and threonine are higher than those of lysine. This happens once lysine requirements are almost exclusively for body protein production. On the other hand, significant amount of the requirements of sulfur amino acid are for feathering. These requirements substantially increase with bird weight and age. In general, when evaluating total requirements, younger birds require a Met+Cys:Lys of 65:100, which increases to 80:100 in 5 to 6-week-old birds Schutte \& Pack (1995b). However, there are little experimental data on the individual use of amino acids, although it is known that lysine is more efficiently used for protein accretion than methionine or other aliphatic amino acids, such as isoleucine (Batterham et al.,1990; Baker, 1991).

Based on broiler growth studies with crystalline amino acids, Baker \& Chung (1992) suggested ratios of $72 \%$ and $67 \%$ for Met+Cys and Thr to lysine. These data are based on the analysis of regression resulting from assays that related protein retention to amino acid intake. Although this is correct, it does not take into account maintenance requirements, which are critical for heavier birds. It must also be remembered that feed efficiency and carcass quality are more important in broilers production than merely growth parameters.

Working with Ross 308 broilers, Schutte \& Pack (1995a) investigated the response to lysine and sulfur amino acids during the period of 14-38 days of age, and verified that the best ratio for Met+Cys:Lys is $82: 100$, when it were evaluated growth rate, feed conversion and breast meat deposition.

The most important parameters to characterize carcass quality are carcass yield, breast meat yield, and carcass fat. Breast meat yield is the carcass component which has the highest financial value, if we consider
Different Criteria for Feed Formulation Based on Digestible Amino Acids for Broilers

the bird as a whole. Within the production cycle, breast meat continuously increases as a percentage of body weight (Acar et al., 1993; Fischer, 1994). If there is any limitation in dietary amino acid supply, breast meat accretion will be the first site of protein synthesis to be affected.

The availability of different nutritional recommendations is a problem in establishing the best nutrition for broilers, as it generates doubts as to which recommendation should be used (Araujo et al., 2002).

This study aimed to evaluate performance and carcass yield of broilers fed according to different feed formulation criteria, based on digestible amino acids for the period of 22 to 42 days of age.

\section{MATERIAL AND METHODS}

The performance and the carcass yield of broilers fed according to different feed formulation criteria, involving digestible methionine, methionine + cysteine, lysine and threonine as recommended by Rostagno et al. (2000), Baker \& Chung (1992), and Degussa (1997), were evaluated for the period of 22 to 42 days of age. Amino acid profiles of each formulation criteria are shown in Table 1.

A total number of six hundred Cobb 500 male dayold chicks were distributed in a completely randomized experimental design, with 3 treatments ( 3 feed formulation criteria) and 4 replicates per treatment, with 50 birds each.

During the starter period ( 1 to 21 days), broilers were raised under the management described by Gomes et al. (1996), and fed a commercial diet for broilers (ME $3.000 \mathrm{kcal} / \mathrm{kg} ;$ CP $21 \%$ ). After that period, birds were selected, weighed, and distributed to the experimental treatments in a completely randomized experimental design. Feed and water were available ad libitum. Birds were housed in a conventional broiler house, measuring $30 \times 6.65 \mathrm{~m}$. The roof was oriented in the north-south direction, with a height of $2.5 \mathrm{~m}$ and had no roof air pipe, and asbestos tiles. The sides were covered by a yellow plastic curtain with a mobile system for the control of the internal house environment. The house was divided in pens measuring $3.15 \times 1.50 \mathrm{~m}$.

The experimental diets were formulated based on corn, soybean meal, corn gluten meal, soybean oil, dicalcium phosphate, limestone, common salt, synthetic amino acids (DL-methionine, L-lysine, and L-threonine), and mineral and vitamin supplements. The basal diet (Table 2) contained the lysine level recommended by Rostagno et al. (2000), and it is shown in Table 3. The 


\section{Araújo LF, Junqueira OM, Araújo CSS, Laurentiz AC, Assuena V, Gomes GA}

diet variables were the amino acid profiles of each evaluated profile. Diets were isoproteic and isocaloric. When profiles were compared, digestible lysine levels remained constant.

\begin{tabular}{|c|c|c|c|c|c|c|}
\hline \multirow{3}{*}{ Amino acids } & \multicolumn{4}{|c|}{ Criterion } & \multirow{2}{*}{\multicolumn{2}{|c|}{$\begin{array}{c}\text { Degussa } \\
1997 \\
\end{array}$}} \\
\hline & \multicolumn{2}{|c|}{$\begin{array}{l}\text { Rostagno } \\
\text { et al. } 2000\end{array}$} & \multicolumn{2}{|c|}{$\begin{array}{c}\text { Baker \& Chung } \\
1992 \\
\end{array}$} & & \\
\hline & $\%$ & DAA & $\%$ & DAA & $\%$ & DAA \\
\hline Lysine & 100 & 1.08 & 100 & 1.08 & 100 & 1.08 \\
\hline Methionine & 39 & 0.42 & 37 & 0.40 & 49 & 0.53 \\
\hline Met+Cys & 70 & 0.76 & 75 & 0.81 & 82 & 0.89 \\
\hline Threonine & 56 & 0.61 & 70 & 0.76 & 60 & 0.65 \\
\hline
\end{tabular}

\begin{tabular}{lccc}
\hline \multirow{2}{*}{ Table 2 - Composition of experimental diets. } \\
\cline { 2 - 4 } Ingredientes & \multicolumn{3}{c}{ Criterion } \\
\cline { 2 - 4 } & Rostagno & Baker \& Chung & Degussa \\
et al. 2000 & $\mathbf{1 9 9 2}$ & $\mathbf{1 9 9 7}$ \\
Corn & 60.37 & 56.60 & 59.22 \\
Soybean meal & 27.96 & 33.09 & 29.67 \\
Corn gluten & 3.47 & 1.02 & 2.35 \\
Soybean oil & 4.16 & 5.33 & 4.62 \\
Dicalcium phosphate & 1.68 & 1.66 & 1.68 \\
Limestone & 1.03 & 1.00 & 1.02 \\
Salt & 0.40 & 0.40 & 0.40 \\
DL-Methionine & 0.15 & 0.24 & 0.30 \\
L-Lysine & 0.28 & 0.16 & 0.24 \\
Vit. mineral premix & 0.50 & 0.50 & 0.50 \\
Total & 100.00 & 100.00 & 100.00 \\
\hline A Suppled per & &
\end{tabular}

A - Supplied per kilogram of diet: Vitamin A - 8,000 Ul; Vitamin $D_{3}$ 2,000 Ul; Vitamin E - 50 mg; Vitamin $\mathrm{K}_{3}-3 \mathrm{mg}$; Vitamin $\mathrm{B}_{1}-1.5 \mathrm{mg}$; Vitamin $B_{2}-4 \mathrm{mg}$; Vitamin $B_{6}-0.12 \mathrm{mg}$; Vitamin $B_{12}-15 \mathrm{mcg}$; Folic acid $-0.6 \mathrm{mg}$; Pantothenic acid - $10 \mathrm{mg}$; Niacin $-30 \mathrm{mg}$; Biotin -0.1 mg; Choline choride - 300 mg; Iron - 50 mg; Copper - 10 mg; Zinc $70 \mathrm{mg}$; Manganese - $100 \mathrm{mg}$; lodine - $1 \mathrm{mg}$; Selenium - $0.3 \mathrm{mg}$; ethoxyquin $-50 \mathrm{mg}$.

\begin{tabular}{lccc}
\hline Table 3 - Calculated composition of experimental diets. \\
\cline { 2 - 4 } Criterion \\
\cline { 2 - 4 } Nutrients & $\begin{array}{c}\text { Rostagno } \\
\text { et al. 2000 }\end{array}$ & $\begin{array}{c}\text { Baker \& } \\
\text { Chung 1992 }\end{array}$ & $\begin{array}{c}\text { Degussa } \\
\mathbf{1 9 9 7}\end{array}$ \\
Energy (kcal ME/kg) & 3,200 & 3,200 & 3,200 \\
Crude protein (\%) & 20.00 & 20.00 & 20.00 \\
Calcium (\%) & 0.91 & 0.91 & 0.91 \\
Non-phytate phosphorus (\%) & 0.42 & 0.42 & 0.42 \\
Sodium (\%) & 0.20 & 0.20 & 0.20 \\
Dig. Lysine (\%) & 1.08 & 1.08 & 1.08 \\
Dig Methionine (\%) & 0.42 & 0.40 & 0.53 \\
Dig Met and Cys (\%) & 0.76 & 0.81 & 0.89 \\
Dig Theonine (\%) & 0.61 & 0.76 & 0.65 \\
\hline
\end{tabular}

The evaluated performance traits were weight gain, feed intake, and feed conversion ratio. Weight gain (WG) was determined by the difference between final weight and initial weight of the broilers in each treatment. Feed intake (FI) was obtained by the difference between the feed fed at the beginning of the experiments and the feed residue of each replicate at the end of the experimental period. Feed conversion ratio (FCR) was determined by the ratio between feed intake during the each experimental period by weight gain during the respective period.

At the end of the experimental period, after 6 hours fasting, four birds of each replicate were slaughtered to determine carcass yield, considered as the eviscerated carcass weight relative to live weight after fasting, before slaughter. Then, the percentage ratios of weights of breast, legs (leg and thighs), wing, back, head (head + neck), feet and abdominal fat (AF) were calculated relative to the eviscerated carcass.

Abdominal fat was defined as the adipose tissue present around the vent, bursa, and adjacent abdominal muscles, according to Smith (1993).

Statistical analyses were carried out using the software SAS - Statistic Analysis System (SAS, 1996). In order to compare the means, the test of Tukey at a level of $5 \%$ was used.

\section{RESULTS AND DISCUSSION}

The performance results of broilers fed diets formulated according to different formulation criteria, based on digestible amino acids, are presented in Table 4. There were no significant differences in weight gain and feed intake among the evaluated treatments ( $p>0.05)$. There was a trend for lower weight gain for the broilers fed the profile established by Rostagno et al. (2000), possibly due to the lower methionine + cysteine and threonine levels recommended by that formulation criterion. For feed conversion, the best results were found in the treatments referring to Baker \& Chung (1992) and Degussa (1997).

\begin{tabular}{|c|c|c|c|}
\hline Criterion & $\begin{array}{l}\text { Weight gain } \\
\text { (g) }\end{array}$ & $\begin{array}{c}\text { Feed } \\
\text { intake }(g)\end{array}$ & $\begin{array}{l}\text { Feed : gain } \\
(g: g)\end{array}$ \\
\hline Rostagno et al., 2000 & $0 \quad 1,498$ & 2,696 & $1.80 \mathrm{~b}$ \\
\hline Baker \& Chung, 1992 & 21,556 & 2,725 & $1.75 a$ \\
\hline Degussa, 1997 & 1,539 & 2,701 & $1.76 a$ \\
\hline CV $(\%)$ & 3.5 & 2.6 & 3.3 \\
\hline$P$ value & 0,123 & 0,085 & 0,043 \\
\hline
\end{tabular}

Means in the same column followed by different letter are different $(p<0.05)$ by Tukey test.

For carcass evaluation (Table 5), no differences were found in leg, wing, back, head + neck, feet, and abdominal contents. The standard established by 


\begin{tabular}{|c|c|c|c|c|c|c|c|c|}
\hline \multirow[b]{2}{*}{ Criterion } & \multirow[b]{2}{*}{ Carcass } & \multicolumn{4}{|c|}{ Parameter } & \multirow[b]{2}{*}{ Head + Neck } & \multirow[b]{2}{*}{ Feet } & \multirow[b]{2}{*}{$\overline{A F}$} \\
\hline & & Breast & Legs & Wings & Back & & & \\
\hline Rostagno et al. 2000 & $86.05 b$ & $26.31 a b$ & 27.31 & 10.43 & 19.56 & 8.71 & 5.19 & 2.49 \\
\hline Baker \& Chung,1992 & $84.94 b$ & $25.75 b$ & 27.37 & 10.50 & 19.27 & 9.41 & 5.27 & 2.43 \\
\hline Dequssa, 1997 & $88.41 a$ & $27.35 a$ & 26.43 & 10.56 & 18.57 & 8.90 & 5.11 & 3.08 \\
\hline$C V(\%)$ & 2.6 & 4.4 & 4.2 & 5.0 & 7.7 & 13.5 & 7.4 & 14.1 \\
\hline$P$ value & 0,038 & 0,029 & 0,087 & 0,102 & 0,153 & 0,144 & 0,095 & 0,071 \\
\hline
\end{tabular}

Means in the same column followed by different letter are different $(p<0.05)$ by Tukey test.

Degussa (1997) promoted the best carcass and breast yield, and that recommended by Baker \& Chang (1992) produced the worst values for carcass and breast yield. Despite not statistically different $(P=0,153)$, the highest back yield was found in birds fed the standard established by Rostagno et al. (2000).

Broilers fed a diet containing 3,000 kcal ME/kg and $1,05 \%$ of digestible lysine, during the period of 14 to 35 of age, presented the best performance when digestible lysine:Met+Cys ratio was 100:75 (Huyghebaert \& Pack, 1995).

Working with broilers during the period of 33 to 43 days of age, and feeding a diet with 3,250 kcal ME/ $\mathrm{kg}$, Shutte \& Pack (1995b) observed that, the best digestible Met+Cys level was approximately $75 \%$ to $78 \%$, and $68 \%$ for threonine as a function of digestible lysine level in the diet, for performance and breast yield.

Araujo et al. (2002) worked with different formulation criteria based on digestible amino acids during the starter phase, and reported that the broilers fed the profiles established by Baker \& Chung (1992) and Degussa (1997) presented better weight gain and feed conversion ratio than those fed diets with the profile recommended by Rostagno et al. (2000). The authors also described that feed intake was not influenced by any of the treatments.

During the finishing phase, using the treatments described in the previous paragraph, Araujo (2001) found better breast yield in birds fed the profiles established by Degussa (1997), which is consistent with the results observed in the present study.

\section{CONCLUSION}

The results of this study allow the following conclusions:

When marketing whole broiler carcasses, the levels established by Degussa (1997) promote the best results for carcass yield and commercial cuts, whereas the results obtained using the levels recommended by Rostagno et al. (2000) were intermediate. However, feed conversion ratio has the worst when broilers were fed with the profile established by Rostagno et al. (2000).

\section{REFERENCES}

Acar N, Moran ET, Mulvaney DR. Breast muscle development of commercial broilers from hatching to twelve weeks of age. Poultry Science 1993; 73:317-325.

Araújo LF. Estudo de diferentes critérios de formulação de rações, com base em aminoácidos totais e digestíveis, para frangos de corte [tese]. Jaboticabal (SP): Universidade Estadual Paulista; 2001.

Araújo LF, Junqueira OM, Araújo CSS, Artoni SMB, Faria Filho DE. Diferentes critérios de formulação de rações para frangos de corte no período de 1 a 21 dias de idade. Revista Brasileira de Ciência Avícola 2002; 4:195-202.

Baker DH. Partitioning of nutrients for growth and other metabolic functions: efficiency and priority considerations. Poultry Science 1991; 70:1797-1805.

Baker DH, Chung TK. Ideal protein for swine and poultry. St Louis: Biokyowa Publishing; 1992. p.1-17

Batterham ES, Andersen LM, Baigent DR, White E. Utilization of ileal digestible amino acids by growing pigs: effect of dietary lysine concentration on efficiency of lysine retention. British Journal of Nutrition 1990; 64:81-98.

Degussa AG. Amino acid recommendations for poultry: feed formulation Guyde. Hanau: Degussa AG; 1997.

Fernandez SR, Aoagi S, Han Y. Limiting order of amino acids in corn and soybean meal for growth of the chick. Poultry Science 1994; 73:1887-1896.

Fischer $C$. Use of amino acids to improve carcass quality of broilers. Feed Mix 1994; 2:17-20.

Gomes PC, Albino LFT, Silva MA. Criação de frangos de corte. Informe Técnico 1996; 17(78):18.

Huyghebaert G, Pack M. The effects of dietary protein concentration and methionine to cysteine balance on the response of broiler chicks to dietary sulfur amino acids. In: European Symposium Nutrition; 1995; Turkey. Proceedings... p. 123-154. 


\section{Araújo LF, Junqueira OM, Araújo CSS, Laurentiz AC, Assuena V, Gomes GA}

Kidd MT, Kerr BJ, Anthony NB. Dietary interactions between lysine and threonine in broilers. Poultry Science 1997; 76:608-614.

Pack M. Proteína ideal para frangos de corte: Conceito e posição atual. In: Conferência Apinco de Ciência e Tecnologia Avícolas; 1995; Curitiba, Brasil. Anais... p.95-110.

Rostagno HS, Albino LFT; Donzele JL. Composição de alimentos e exigências nutricionais de aves e suínos: tabelas nrasileiras. Viçosa, MG: UFV; 2000. p.141.

SAS Institute. User's guide: statistics. Cary, NC: SAS Institutte; 1996. Schutte JB; Pack M. Sulfur amino acid requirement of broiler chicks from 14 to 38 days of age. 1. Performance and carcass yield. Poultry Science 1995a; 74:480-487.

Schutte JB, Pack M. Effects of dietary methionine and cystine on growth and breast meat deposition in growing and finishing broilers. British Poultry Science 1995b; 36:747-762.

Smith MO. Parts yield of broilers reared under cycling high temperatures. Poultry Science 1993; 72:1207-1214. 